\title{
Adapting the Scale for Spiritual Intelligence to Turkish
}

\author{
Özge Erduran-Tekin ${ }^{1}$ \\ Tekirdağ Guidance and Research Center
}

\author{
Halil Ekşi ${ }^{2}$ \\ Marmara University
}

\begin{abstract}
The purpose of this study is to adapt the Scale for Spiritual Intelligence Scale developed by Kumar and Mehta (2011) into Turkish and to examine its reliability and validity. Data have been collected from four different study groups involving a total of 1,098 high school students ( 440 females and 658 males). In Turkey, the exploratory factor analysis of the Scale for Spiritual Intelligence's original structure, which consists of six factors, only appears to have occurred in four cases. The goodness-of-fit statistics obtained as a result of the confirmatory factor analysis performed on one sample using this structure are $X^{2}=335.17$, $\mathrm{SD}=145\left(X^{2} / \mathrm{SD}=2.33\right), \mathrm{RMSEA}=0.052, \mathrm{SRMR}=0.049, \mathrm{GFI}=0.93, \mathrm{CFI}=0.90, \mathrm{AGFI}=0.91$. Whether or not a statistically significant difference exists in the scores for the lower and upper 27th-percentile groups was examined in order to look at the discriminators of the scale; a statistically significant difference has been detected in favor of the upper segment. As a result of the criterion validity study, a significant positive correlation has been found between the Scale for Spiritual Intelligence and the Meaning in Life Scale (Demirbass, 2010). According to the obtained linguistic equivalence results, the Turkish form of the scale is seen to be equivalent to the original English form. Cronbach's alphas of internal consistency and reliability were calculated as .86 and .85 for both samples. Research results reveal the Turkish form of Scale for Spiritual Intelligence to be a valid and reliable instrument that can be used in scientific studies to be carried out in Turkey.
\end{abstract}

Keywords:

Spiritual intelligence, Scale adaptation, Validity, Reliability, Adolescent

Manevi Zekâ Ölçeği' nin Türkçe' ye Uyarlanması

$\ddot{\mathrm{O} z}$

Bu çalışmanın amacı Kumar ve Mehta (2011) tarafından geliștirilen, ergenlere uygulanan Manevi Zekâ Ölçeği'ni Türkçe'ye uyarlayarak geçerlik ve güvenirliğini incelemektir. Araştırmaya dört ayrı çalışma grubundan oluşan 440 kız ve 658 erkek olmak üzere toplam 1098 lise ögrencisi katılmıștır. Açımlayıcı faktör analizi sonucunda orijinal yapısı altı faktörden oluşan Manevi Zekâ Ölçeği'nin sadece 4 faktörünün Türkiye örnekleminde ortaya çıktı̆̆ı görülmektedir. Doğrulayıcı faktör analizi sonucunda ulaşllan uyum iyiliği istatistikleri $\left[\left(X^{2}=335.17, \mathrm{sd}=145\left(X^{2} / \mathrm{sd}=2.33\right)\right.\right.$, RMSEA 0.052, SRMR=0.049, GFI=0.93, CFI=0.90, AGFI=0.91] șeklindedir. Manevi Zekâ Ölçeği' nin ayırt ediciliğini incelemek için \%27'lik alt dilimde ve \%27'lik üst dilimde yer alan katılımcılardan oluşan iki grubun puanlarının istatistiksel olarak farklılık gösterip göstermediği incelenmiş, alt ve üst gruplar arasında üst grup lehine istatistiksek olarak anlamlı bir farklılık tespit edilmiştir. Ölçüt bağlantı geçerlik çalışması sonucunda Manevi Zekâ Ölçeği ile Yaşamda Anlam Ölçeği (Demirbaş, 2010) arasında pozitif yönlü anlamlı ilişki bulunmuş ve elde edilen dilsel eşdeğerlik sonuçlarına göre de ölçeğin Türkçe formunun, orijinal İngilizce formuna eşdeğer olduğu görülmüştür. İç tutarlık güvenirlik Cronbach's Alpha katsayısı ölçeğin tümü için her iki örneklemde de hesaplanmıș, .86 ve .85 olarak bulunmuştur. Araştırma sonuçları Manevi Zekâ Ölçeği’ nin Türkçe formunun geçerli ve güvenilir bir ölçme aracı olduğunu ve Türkiye'de yürütülecek bilimsel çalışmalarda kullanılabileceğini ortaya koymuştur.

\section{Anahtar Kelimeler:}

Manevi zekâ, ölçek uyarlama, geçerlik, güvenirlik, ergenlik.

1 Correspondence to: Özge Erduran-Tekin (Counseling Specialist). Tekirdağ Guidance and Research Center. Hürriyet Mah. Ögretmenler Cad. No: 26, 59100Süleymanpaşa/Tekirdağ TURKEY E-mail: pskdanozgeerduran@gmail.com

2 Department of Educational Sciences, Marmara University, Istanbul, Turkey. Email: halileksi@marmara.edu.tr Citation: Erduran-Tekin, Ö., \& Ekşi, H. (2019). Adapting the Scale for Spiritual Intelligence to Turkish. Spiritual Psychology And Counseling 4, 123-141. http://dx.doi.org/10.37898/spc.2019.4.2.0062 
Experiencing identity crisis in adolescence is a part of the normal development process. This period of crisis involves adolescents questioning previously accepted ideas, values, and beliefs and discovering different belief systems and lifestyles (Erikson, 1980). This period results in committing to a chosen life path and a system of values and beliefs. In order for a youth to feel ready for life as an adult, one's sense of identity must be sufficiently established. Therefore, when a sense of identity has not been sufficiently established, especially in individuals near the end of puberty, this constitutes a conflict and sometimes significantly disrupts the person's harmony (Dereboy \& Dereboy, 1997; Derman 2008). In order to establish a positive balance among proper thoughts, speech, and actions, adolescents whose adaptation has been disrupted within the complexity of acquiring their identity must complete their identity complex, which also relates to their spiritual intelligence (Kumar \& Mehta, 2011).

Vaughan (2002) argued that spirituality takes place in one's mind and heart, free of religion and tradition. Spirituality can be conscious or subconscious, developed or underdeveloped, healthy or pathological, pure or chaotic, useful or harmful. Wigglesworth (2012) defined spirituality as the meaning and meta-personal aspects that man attributes to something endowed with spirituality. Zohar and Marshall are the first researchers to uncover the concept of spiritual intelligence as associated with spirituality. Zohar and Marshall (2000) defined spiritual intelligence as the intelligence with which an individual addresses and solves problems of meaning and value and where one can place one's actions and life in a broader, richer, meaningful context. Spiritual intelligence is a kind of intelligence that includes IQ (intelligence quotient) and EQ (emotional quotient) and extends beyond these quotients (Bozdağ, 2005). In this sense, spiritual intelligence has been stated as a type of intelligence that integrates all intelligences. Nasel (2004) described spiritual intelligence as the ability to use one's spiritual skills and resources to better define, understand, and solve existential, spiritual, and practical problems. Such resources and abilities are related to praying, having intuition or being transcendent, finding meaning in the individual's experiences, facilitating the resolution of problems, and increasing the capacity of an individual to make decisions. When looking at the adolescent development process in general based on all these spiritual and spiritual-intelligence explanations, spiritual intelligence can be stated to be an important source in the processes of gaining identity, spiritual development, forming values and meaning in adolescence, and providing adolescents with new perspectives.

Spiritual intelligence helps adolescents find meaning in life (Nazam, 2014) and contributes to adolescents' moral development and formation of a values system. It also predicts the adolescent's emotional, social, and educational adaptation as well as scholastic performance (Kumar \& Mehta, 2011). Vaughan (2002) described spiritual intelligence as the ability to create meaning in life based on awareness of the in- 
depth understanding of existential questions and the ability to use multiple levels of consciousness to solve problems and achieve goals. When examining the neurological basis of spiritual intelligence, neuropsychologist Persinger (1996) and neurologist Ramachandran (1998) conducted studies on the presence of the God module in the human brain with a team from the University of California. The established mental center was found to be located between the neural connections in the temporal lobes of the brain. Again, Hamer (2004) found a gene that contributes to the self-reported value of self-transcendence in the study of siblings of the same gender.

According to Erikson (1980), adolescents who are involved in identity acquisition and role confusion complete this period from a developmental perspective by finding their meaning and purpose in life. In this period, the balance between one's thoughts and actions for creating purpose and finding meaning is also based on the spiritual aspect. Looking at the definitions in general, spiritual intelligence is the ability to use spiritual abilities and resources to find meaning and solve problems. On this point, being able to measure adolescents' spiritual intelligence contributes to adolescents being able to pass the period more healthily, define themselves better by looking from the outside, create a values system, and support their moral development, as well as for being able to work with adolescents who bring spirituality as a therapeutic tool to the consultation. In Turkey, no measurement tool has been found developed or adapted for measuring the spiritual intelligence of high school students. The idea behind developing this scale adaptation is to establish the concept of spiritual intelligence in collectivist cultures connected to Eastern philosophy and to evaluate this concept in adolescents. The concept of spiritual intelligence has been described in various aspects using theoretical foundations after analyzing the narratives of distinguished scientists in the region and reviewing the literature on spiritual intelligence.

From an existential point of view, man alone is an entity that seeks meaning in life and strives for greater common good. Certain innate potentials are naturally added to each individual and can develop with adequate nurturing. Transforming this concept into a narrative is necessary if we need to take a look at the conceptualization and importance of spiritual intelligence, especially in terms of its presence in adolescents. Moreover, most of the scales developed in the region focus on spirituality more than spiritual intelligence, and rarely has such a scale been developed for adolescents. For this reason, making this concept operational by taking an eclectic mix of various schools of thought in the world is considered an appropriate effort, and the Scale for Spiritual Intelligence was developed for evaluating adolescents' levels of spiritual intelligence (Kumar \& Mehta, 2011). Adapting of this scale, which was developed based on Eastern philosophy, is considered to be able to make an important contribution to the literature in terms of being the first measurement tool adapted to Turkish culture for measuring high school students' spiritual intelligence. Furthermore, adapting 
such a measurement tool can contribute to mental health experts who work in the field for evaluating adolescents' spiritual intelligence, seeing the role of spirituality in adolescent life, showing adolescents their spiritual resources, and organizing counseling sessions for adolescents.

\section{Method}

\section{Study Group}

The population of the study consists of high school students studying in Tekirdağ city. The data in this study were collected from four randomly-selected study groups. Firstly, 42 students (22 girls, 20 boys, 52.6\% female, $47.6 \%$ male, $M_{\text {age }}=15.64 S D_{\text {age }}$ $=0.65$ ) studying in the Foreign Language Department of the Tekirdağ Municipality Social Sciences High School and enrolled in the study for linguistic equivalence in the 2018 fall semester. To determine the construct validity of the scale, data were collected for exploratory factor analysis from a second group consisting of 531 students (201 girls, 330 boys) studying at the high schools of Süleymanpaşa Anatolian Imam Hatip (project school), Tekirdağ Fatih Anatolian, Namık Kemal, Tekirdağ Anatolian Imam Hatip, and Tekirdağ Nene Hatun Anatolian Girls Imam Hatip. Participants' (62.1\% male and $37.9 \%$ female) mean age is $16.05(S D=.87)$. Data were also collected for confirmatory factor analysis from another group consisting of 485 students (201 girls, 284 boys) studying in different classes at the high schools of Süleymanpaşa Anatolian Imam Hatip (project school), Tekirdağ Anatolian Imam Hatip, Tekirdağ Municipality Social Sciences, Tekirdağ Fatih Anatolian, and Tekirdağ Nene Hatun Anatolian Girls Imam Hatip. The mean age of the participants in the third study group (58.6\% male, $41.4 \%$ female), has been calculated as $16.04(S D=.87)$. A total of 40 students (16 girls, 24 boys, $40 \%$ female, $60 \%$ male, $M_{\text {age }}=15.73, S D=.78$ ) from Tekirdağ Municipality Social Sciences High School were enrolled for the criterionrelated validity study.

\section{Data Collection Tools}

Information about the measurement tools used to collect data from the participants in the scope of the research is presented below.

Demographic information form. A demographic information form prepared by the researcher has been used to collect information about the demographic characteristics of the students who participated in the study. This form contains questions about the variables of gender and age.

Spiritual Intelligence Scale (SSI). This was developed by Kumar and Mehta (2011) for forming the concept of spiritual intelligence in collectivist cultures based 
on Eastern philosophy and measuring adolescents' spiritual intelligence. Taking an eclectic mix of various schools of thought in the world was considered appropriate for attempting to make this concept functional. The scale is short, standard, and easy to use and grade. When developing the scale, 80 items were initially written; the number of items was decreased to 20 after being shown to field-related experts, and then the necessary analyses were performed. It was applied to 450 Indian male adolescents aged 14-17 years. The construct validity of the scale was performed over 100 groups of students. Factor analysis was performed using principal component analysis and Kaisar varimax rotation. A total of six factors were obtained by considering the factors with an eigenvalue greater than 1 . The six factors share $59.61 \%$ of the common variance. Items with a loading value greater than \pm 35 were thought to be psychologically significant when labeling these factors. A total of 20 items were loaded as significant on the six obtained factors, thus the scale is assumed to consist of 20 items. The scale has six sub-dimensions: purpose in life (Items 11, 20, 8, 5, 12, 2, and 9), human values (Items 13, 16, 14, 17, and 7), compassion (Items 6, 3, 10, 12, 18, and 14), commitment to humanity (Items 19, 18, and 20), self-understanding (Items 4, 1, 10, and 2), and conscience (Items 15, 9, 7). The Scale for Spiritual Intelligence is associated with the Self Compassion Scale (Raes, Pommier, Neff, \& Van Gucht, 2011) and the Psychological Wellbeing Scale (Ryff \& Keyes (1995). No time limit exists for completing the scale, but the first thing that comes to mind is preferred for the answer, and no answers should be left blank. It can be finished in an average of 10 minutes. The scale items are composed as 5-point Likert type questions. The total score is obtained by adding the scores from the sub-dimensions. Adolescents with high scores can be said to have high spiritual intelligence. Ten items on the scale are reverse-scored (Items 1, 3, 4, 7, 9, 13, 14, 15, 16, and 17). Cronbach's alpha of reliability for the scale has been found as .78.

Meaning in Life Scale. It was developed by Steger, Frazier, Oishi, and Kaler (2006) and consists of 10 items. The scale has two independent sub-dimensions: the existence of meaning in life and searching for meaning in life. The sub-dimension of existence of meaning in life consists of five items (Items 1, 4, 5, 6, and 9). The Item 9 is reverse scored. The dimension of search for meaning in life consists of five items (Items 2, 3, 7, 8, and 10). The scale is scored as a 7-point Likert-type question. The lowest and highest scores obtainable from each sub-dimension are 5 and 35 . Higher scores obtained from a sub-dimension on the scale indicate the individual to have more of the characteristics represented by that dimension. Cronbach's alpha of reliability for the scale is 0.88 for the sub-dimension of existence of meaning in life and 0.93 for the sub-dimension of' searching for meaning in life. The Meaning in Life Scale was adapted to Turkish culture and its validity ensured over 300 university students by Demirbaş (2010). Afterwards, the Meaning in Life Scale was applied to 350 high school students from two different high school types in order to 
determine their psychometric properties (Demirbaş Çelik, \& İşmen Gazioğlu, 2015). Exploratory and confirmatory factor analyses were performed for the validity study of the scale. The reliability of the scale was calculated using Cronbach's alpha of reliability, test-retest, and item-total correlation coefficient methods. As a result of the analyses, confirmation of the dual factor structure of the scale was determined to the same for university students as for high school students, and the results showed the scale to be a valid and reliable tool for high school students.

\section{Data Collection Process}

For the cultural adaptation study of the Scale for Spiritual Intelligence, first the developer of the scale, Kumar, was contacted by e-mail and the permission required for adapting the scale was obtained. Next, the scale was translated into Turkish by six experts competent in English and Turkish. The Turkish form was translated back to English by two experts, and consistency between the two forms was examined. The new form, which was composed of meaning and grammar, was not determined to differ from the original form. Afterwards, five experts working in the Guidance and Psychological Counseling Department examined the scale and stated that the scale was appropriate. Afterwards, the English form was applied to 42 students studying in the Foreign Language Department of Tekirdağ Social Sciences High School, and one week later the Turkish form was applied. After giving the participants the necessary information about the research, the measurement tools were applied face to face. Methods for linguistic equivalence, criteria-related validity, internal consistency reliability, exploratory factor analysis, and confirmatory factor analysis were applied for analyzing the data. The validity and reliability studies for the Scale for Spiritual Intelligence were completed using the data collected from the students within the scope of the research in SPSS 25 and LISREL 8.51 (Joreskog \& Sörbom, 2001). For the factor analysis planned within the scope of the research, the suitability of the data and the sample size were examined, and the data obtained from both study groups were determined to be sufficient for factor analysis (Tabachnick \& Fidel, 2001).

Confirmatory factor analysis (CFA) was applied first; the analysis was started and the structure of the scale was confirmed for Turkish culture. Next, Exploratory factor analysis (EFA) was completed using varimax rotation and principal component analysis in order to determine the construct validity of the Scale for Spiritual Intelligence. After completing the EFA, the item-total correlation was calculated in examining the analysis of the items related to the Scale for Spiritual Intelligence Scale. Another CFA was done to test the accuracy of the sample against the structure set forth by the EFA for the Turkish Scale for Spiritual Intelligence. The analyses were completed using LISREL 8.51 (Joreskog \& Sörbom, 2001) and the method of estimating all the information with the greatest probability. As a result of the analysis, 
using the values summarized in Table 1 below was decided for evaluating the scale's compliance levels.

Table 1.

Model Compliance Evaluation Criteria

\begin{tabular}{ccc}
\hline Measure of Fit & Good Fit & Acceptable Fit \\
\hline$\chi^{2} / S D$ & $0 \leq \chi^{2} / S D \leq 2 S D$ & $2 S D \leq \chi^{2} / S D \leq 3 S D$ \\
$R M S E A$ & $0 \leq R M S E A \leq 0.05$ & $0.05 \leq R M S E A \leq 0.08$ \\
$S R M R$ & $0 \leq S R M R \leq 0.05$ & $0.05 \leq S R M R \leq 0.10$ \\
$C F I^{1}$ & $0.95 \leq C F I \leq 0.97$ & $0.97 \leq C F I \leq 1.00$ \\
$G F I$ & $0.95 \leq G F I \leq 1.00$ & $0.90 \leq G F I \leq 0.95$ \\
$A G F I$ & $0.85 \leq A G F I \leq 0.90$ & $0.90 \leq A G F I \leq 1.00$ \\
\hline
\end{tabular}

${ }^{1}$ (Çelik \& Yılmaz, 2014; Hu \& Bentler, 1999; Marsh, Hau \& Wen, 2004; MacCallum \& Hong, 1997; Schermelleh-Engel, Moosbrugger \& Muller, 2003; Sümer, 2000; Şimşek, 2007; Tabachnick \& Fidel, 2001)

After testing the construct validity of the Scale for Spiritual Intelligence using EFA and CFA, the reliability of the scale's overall scores was calculated using Cronbach's alpha of internal consistency. In addition, Pearson correlation analysis was conducted to reveal the relationships among the sub-dimensions of the Scale for Spiritual Intelligence Scale.

\section{Results}

\section{Exploratory Factor Analysis (EFA) Results}

In order to test the construct validity of the Scale for Spiritual Intelligence, EFA was performed using principal components analysis. However, before starting the EFA, the Kaiser-Meyer-Olkin coefficient (KMO) and Barlett sphericity values were calculated to test whether the data set was suitable for factor analysis (Büyüköztürk, 2010). As a result of the analysis, $K M O$ was calculated as 0.88 and Bartlett sphericity as 2,643.813 $(p<0.001)$. As a result of the calculation, the measuring instrument was determined to be suitable for factor analysis, and the analysis was completed using varimax, a vertical rotation method. After the analysis, the scale was seen to be gathered under five factors with Eigen values greater than 1.00. The total variance explained by these five factors in relation to the Scale for Spiritual Intelligence has been calculated as $53.15 \%$.

After all these analyses, the fifth factor was observed to consist of only Item 3 (see Table 2). Because the third item constitutes a single dimension, excluding the item from the analysis and repeating the EFA was decided. However, before starting a new EFA, the $K M O$ and Bartlett sphericity value were calculated to test whether the data set was suitable for factor analysis (Büyüköztürk, 2010). As a result of the analyses, the $K M O$ was calculated as 0.88 and the Bartlett sphericity value as 2,551.450 $(p<0.001)$. Considering all these values, the data set was determined to be suitable for doing a new EFA. The values obtained as a result of the second EFA are presented in Table 3. 
Table 2 .

Factor Loadings for the Items from the Scale for Spiritual Intelligence (X, SD, and Post-Rotation)

\begin{tabular}{|c|c|c|c|c|c|c|c|}
\hline Items & & $S D$ & Factor I & Factor II & Factor III & Factor IV & Factor V \\
\hline MZ10 & 3.53 & 1.09 & .682 & & & & \\
\hline MZ1 & 4.10 & .80 & .646 & & & & \\
\hline MZ17 & 1.89 & 1.02 & .605 & & & & \\
\hline MZ20 & 4.40 & .72 & .571 & & & & \\
\hline MZ5 & 3.90 & .70 & .569 & & & & \\
\hline MZ2 & 3.93 & .82 & .525 & & & & \\
\hline MZ8 & 3.79 & 1.11 & .520 & & & & \\
\hline MZ14 & 4.09 & .90 & & .732 & & & \\
\hline MZ15 & 4.44 & .86 & & .730 & & & \\
\hline MZ13 & 3.73 & 1.03 & & .674 & & & \\
\hline MZ16 & 4.23 & .65 & & & & & \\
\hline MZ12 & 3.86 & .83 & & & .694 & & \\
\hline MZ18 & 3.78 & .96 & & & .644 & & \\
\hline MZ11 & 3.93 & .92 & & & .632 & & \\
\hline MZ19 & 3.39 & 1.11 & & & .595 & & \\
\hline MZ6 & 4.10 & .82 & & & .519 & & \\
\hline MZ9 & 3.84 & .71 & & & & .758 & \\
\hline MZ4 & 3.80 & .78 & & & & .556 & \\
\hline MZ7 & 3.92 & .67 & & & & .534 & \\
\hline MZ3 & 4.08 & .66 & & & & & -.808 \\
\hline
\end{tabular}

Table 3.

Factor Loadings of the Items from the Scale for Spiritual Intelligence ( $\bar{X}, S D$, and Post-Rotation)

\begin{tabular}{|c|c|c|c|c|c|c|}
\hline Items & & $S D$ & Self Understanding & Human Values & Compassion & Conscience \\
\hline MZ10 & 3.53 & 1.09 & .674 & & & \\
\hline MZ1 & 4.10 & .80 & .626 & & & \\
\hline MZ20 & 4.40 & .72 & .600 & & & \\
\hline MZ5 & 3.90 & .70 & .588 & & & \\
\hline MZ17 & 3.93 & .82 & .586 & & & \\
\hline MZ2 & 3.79 & 1.11 & .525 & & & \\
\hline MZ8 & 4.09 & .90 & .491 & & & \\
\hline MZ15 & 4.44 & .86 & & .730 & & \\
\hline MZ14 & 3.73 & 1.03 & & .727 & & \\
\hline MZ13 & 4.23 & .65 & & .672 & & \\
\hline MZ16 & 3.86 & .83 & & .411 & & \\
\hline MZ12 & 3.78 & .96 & & & .679 & \\
\hline MZ18 & 3.93 & .92 & & & .644 & \\
\hline MZ11 & 3.39 & 1.11 & & & .636 & \\
\hline MZ19 & 4.10 & .82 & & & .605 & \\
\hline MZ6 & 3.84 & .71 & & & .545 & \\
\hline MZ4 & 3.80 & .78 & & & & .686 \\
\hline MZ9 & 3.92 & .67 & & & & .682 \\
\hline MZ7 & 4.08 & .66 & & & & .552 \\
\hline
\end{tabular}


The descriptive statistics and factor loadings of the items related to the four factors that emerged regarding the Scale for Spiritual Intelligence are given in Table 3. As can be seen in Table 3, factor loadings for the first dimension vary between .674 and .491 and consist of seven items. Factor loadings for the items collected under the second dimension consist of four items and vary between .411 and .730 . The third dimension of the scale consists of five items, and the factor loadings vary between .545 and .679 . The fourth dimension of the scale consists of three items, and the factor loadings for these items vary between .552 and .686 . As a result of the completed analyses, the four factors from the Scale for Spiritual Intelligence Scale are seen to explain $49.851 \%$ of the explained variance. The first factor explains $15.242 \%$ of the total variance and consists of items about self-understanding. For this reason, the first factor from the Scale for Spiritual Intelligence has been called Self-Understanding. The second factor from the scale explains $12.752 \%$ of the total variance, and the items appear to relate to human values. Therefore, the second factor has been called Human Values. The third factor from the Scale for Spiritual Intelligence explains $12.705 \%$ of the total variance, and the items under this factor appear to relate to compassion. Accordingly, this factor is called Compassion. The fourth factor from the scale explains $9.192 \%$ of the total variance, and the content of the items relate to the phenomenon of conscience. Therefore, the fourth factor from the scale has been named Conscience.

The Scale for Spiritual Intelligence, which consists of six factors (i.e., selfunderstanding, human values, compassion, conscience, commitment towards humanity, and purpose of life) according to the results from the completed EFA, consists of only four factors for the Turkish version. These four factors are self-understanding, human values, compassion, and conscience. This can be considered a result of many different reasons: adolescents start to develop at different times, adolescents progress differently in this process and have varying accelerations in cognitive development through the identity formation process, adolescents experience different individualization processes, spiritual development based on abstract processes from the cognitive perspective is only possible with adequate and appropriate cognitive development, and the cultural and environmental factors that affect adolescent attitudes. This is also thusly considered to be affirmed in Turkish culture.

\section{Confirmatory Factor Analysis (CFA) Results}

The model formed by LFAR 8.51 (Joreskog \& Sörbom, 2001) for confirming the structure of the Scale for Spiritual Intelligence that resulted from the EFA has been presented in Figure 1. 


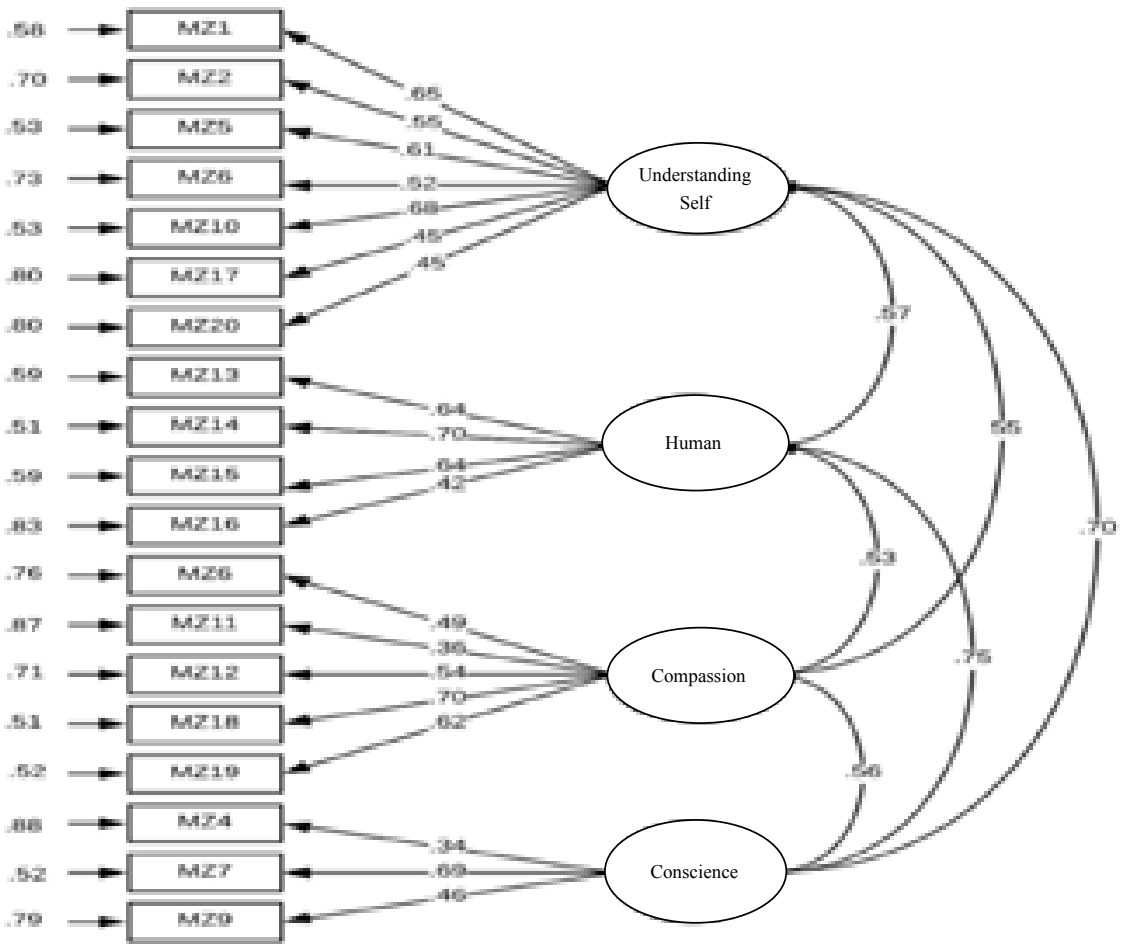

Figure 1. Confirmatory factor analysis for the Scale for Spiritual Intelligence.

The factor loadings $(\lambda), t$, and $R^{2}$ values obtained from the CFA are presented in Table 4.

Table 4.

Standardized Factor Loadings, $\mathrm{t}$, and $\mathrm{R}^{2}$ Values from the Scale for Spiritual Intelligence

\begin{tabular}{llcccccc}
\hline Items & $\Lambda$ & $\boldsymbol{t}$ & $\boldsymbol{R}^{\mathbf{2}}$ & Items & $\Lambda$ & $\boldsymbol{t}$ & $\boldsymbol{R}^{\mathbf{2}}$ \\
\hline MZ1 & .65 & 14.61 & .42 & MZ6 & .49 & 10.07 & .24 \\
MZ2 & .55 & 11.86 & .30 & $\mathbf{M Z 1 1}$ & .36 & 7.24 & .13 \\
MZ5 & .61 & 13.53 & .37 & MZ12 & .54 & 11.19 & .29 \\
MZ8 & .52 & 11.21 & .27 & MZ18 & .70 & 15.14 &. .49 \\
MZ10 & .68 & 15.55 & .47 & MZ19 & .62 & 13.05 & .38 \\
MZ17 & .45 & 9.50 & .20 & MZ4 & .34 & 6.57 & .12 \\
MZ20 & .45 & .9 .45 & .20 & MZ7 & .69 & 12.64 & .48 \\
MZ13 & .64 & 13.79 & .41 & MZ9 & .46 & 8.84 & .21 \\
MZ14 & .70 & 15.43 & .49 & & & & \\
MZ15 & .64 & 13.81 & .41 & & & & \\
MZ16 & .42 & 8.51 & .17 & & & & \\
\hline
\end{tabular}

Model adaptation statistics for the Scale for Spiritual Intelligence are presented in Table 5. 
Table 5.

Model Compliance Statistics for the Scale for Spiritual Intelligence

\begin{tabular}{lcc}
\hline Adaptation Size & Value & Fit \\
\hline$X^{2} / S D$ & 2.59 & Acceptable Fit \\
$R M S E A$ & 0.057 & Acceptable Fit \\
$S R M R$ & 0.051 & Acceptable Fit \\
$C F I^{1}$ & 0.89 & Bad Fit \\
$G F I$ & 0.92 & Acceptable Fit \\
$A G F I$ & 0.90 & Acceptable Fit \\
\hline
\end{tabular}

${ }^{1}$ (Çelik \& Y1lmaz, 2014; Hu \& Bentler, 1999; Marsh, Hau \& Wen, 2004; MacCallum \& Hong, 1997; Schermelleh-Engel, Moosbrugger \& Muller, 2003; Sümer, 2000; Şimşek, 2007; Tabachnick \& Fidel, 2001)

The goodness-of-fit statistics obtained as a result of the CFA are $\chi^{2}=378.51, S D=$ $146, \chi^{2} / S D=2.59, R M S E A=0.057, S R M R=0.051, G F I=0.92, C F I=0.89$, and $A G F I$ $=0.90$; the reported goodness-of-fit values from the measuring instrument mostly show acceptable fit. However, in order to achieve better model fit, the proposed suggestions for corrections were examined; in light of these suggestions, the modification that constitutes the biggest difference in the $\chi^{2}$ value was seen to be formed by associating the errors from Items 1 and 10 from the Scale for Spiritual Intelligence. As a matter of fact, when examining the contents of the scale items, both items are seen to be in the sub-dimension of Understanding Self; the scale items are similar in meaning, which theoretically supports the proposed modification. Accordingly, applying the proposed modification index was determined. As a result of the analyses, the model that emerged as a result of CFA after correcting the Scale for Spiritual Intelligence is given in Figure 2.

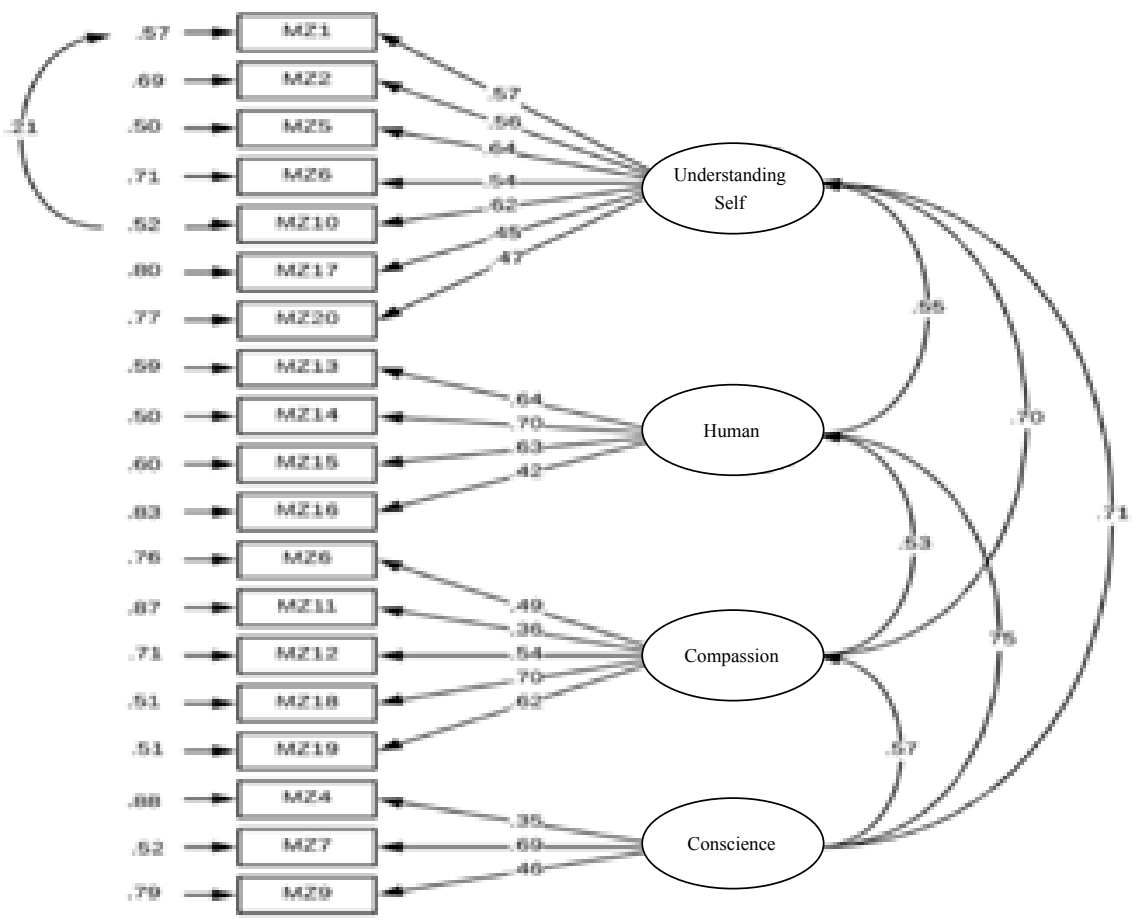

Figure 2. Post-Correction CFA results from the Scale for Spiritual Intelligence. 
The factor loadings $(\lambda), t$, and $R^{2}$ values obtained for the items after correction are presented in Table 6 .

Table 6.

Standardized Factor Loadings, $\mathrm{t}$ and $\mathrm{R}^{2}$ Values from the Scale for Spiritual Intelligence After Correction

\begin{tabular}{lccccccc}
\hline Items & $\lambda$ & $\boldsymbol{t}$ & $\boldsymbol{R}^{\mathbf{2}}$ & Items & $\Lambda$ & $\boldsymbol{t}$ & $\boldsymbol{R}^{\mathbf{2}}$ \\
\hline MZ1 & .57 & 12.21 & .33 & MZ6 & .49 & 10.13 & .24 \\
MZ2 & .56 & 11.96 & .31 & MZ11 & .36 & 7.20 & .13 \\
MZ5 & .64 & 13.96 & .40 & MZ12 & .54 & 11.19 & .29 \\
MZ8 & .54 & 11.53 & .29 & MZ18 & .70 & 15.13 & .49 \\
MZ10 & .62 & 13.36 & .38 & MZ19 & .62 & 13.18 & .38 \\
MZ17 & .45 & 9.38 & .20 & MZ4 & .35 & 6.60 & .12 \\
MZ20 & .47 & 9.92 & .23 & MZ7 & .69 & 12.60 & .48 \\
MZ13 & .64 & 13.82 & .41 & MZ9 & .46 & 8.86 & .21 \\
MZ14 & .70 & 15.46 & .50 & & & & \\
MZ15 & .63 & 13.68 & .40 & & & & \\
MZ16 & .42 & 8.49 & .17 & & & & \\
\hline
\end{tabular}

Model adaptation statistics for the Scale for Spiritual Intelligence are also presented in Table 7.

Table 7.

Model Adaptation Statistics for the Scale for Spiritual Intelligence

\begin{tabular}{ccc}
\hline Adaptation Size & Value & Fit \\
\hline$\chi^{2} / S D$ & 2.33 & Acceptable Fit \\
$R M S E A$ & 0.052 & Acceptable Fit \\
$S R M R$ & 0.049 & Good Fit \\
$C F I^{1}$ & 0.90 & Acceptable Fit \\
$G F I$ & 0.93 & Acceptable Fit \\
$A G F I$ & 0.91 & Acceptable Fit \\
\hline
\end{tabular}

${ }^{1}$ (Çelik \& Y1lmaz, 2014; Hu \& Bentler, 1999; Marsh, Hau \& Wen, 2004; MacCallum \& Hong, 1997; Schermelleh-Engel, Moosbrugger \& Muller, 2003; Sümer, 2000; Şimşek, 2007; Tabachnick \& Fidel, 2001)

The goodness-of-fit statistics obtained as a result of the CFA are $\chi^{2}=335.17, S D$ $=145, \chi^{2} / S D=2.33, R M S E A=0.052, S R M R=0.049, G F I=0.93, C F I=0.90$, and $A G F I=0.91$; the reported compliance values for goodness of fit show the measuring instrument to have good and acceptable fit. For this reason, the Scale for Spiritual Intelligence Scale can be said to be a valid measuring instrument for the case of Turkey.

\section{Reliability of the Scale for Spiritual Intelligence}

Cronbach's alpha of internal consistency has been calculated to test the reliability of each factor from the Scale for Spiritual Intelligence as well as the entire scale. 
Table 8.

Cronbach's Alpha of Internal Consistency for Each Factor and the Entire Scale

\begin{tabular}{lcc}
\hline Factors & $\begin{array}{c}\text { Cronbach's alpha of internal } \\
\text { consistency (1st Study Group) }\end{array}$ & $\begin{array}{c}\text { Cronbach's alpha of internal } \\
\text { consistency (2nd Study Group) }^{\mathbf{b}}\end{array}$ \\
\hline Self Understanding & .77 & .76 \\
Human Values & .71 & .70 \\
Compassion & .71 & .70 \\
Conscience & .66 & .68 \\
Overall Scale & .86 & .85 \\
\hline
\end{tabular}

${ }^{\mathrm{a}} n=530,{ }^{\mathrm{b}} n=485$

According to the obtained results, Cronbach's alpha for the total scores from the Scale for Spiritual Intelligence is seen to be .86 for the first sample and .85 for the second; both are reliable. One of the biggest difficulties in approaching adolescents is that their development processes do not start at the same time but at different times for each adolescent. Therefore differences can exist among the adolescents in the same class in terms of developmental stages as well as individual development for the same adolescent within a year. During adolescence, developments exist specific to it, such as accelerated cognitive development and experiencing individualization processes alongside identity formation (Derman, 2008). Therefore, individual differences are prominent even among adolescents in the same grade. Moreover, a fully matured moral structure cannot be mentioned prior to puberty.

In fact, understanding and adopting moral assumptions based on abstract cognitive processes is possible only with sufficient and appropriate cognitive development. In this context, a tendency towards moral maturity can develop only in parallel with the development of abstract thought during adolescence. Regarding the relationship between developing a conscience and feeling guilt within the framework of moral development during adolescence, adolescents rebel against the conscientious structure that occurred in their childhood and try to resolve the conflict between the desire to be free of conscience and being a prisoner of conscience by challenging those around them verbally and by behaving methodically in accordance with the standards set by society (Koç, 2004). Given all these factors and dilemmas and considering the difficulty of measuring an abstract concept such as spirituality in adolescents whose abstract thinking process has not fully formed, lower scores in the sub-dimension of conscience can be considered due to this. Testing this sub-dimension in other samples would be appropriate.

\section{Linguistic Equivalence Study of the Scale for Spiritual Intelligence}

The correlation coefficients between the overall scores from the English form for the 42 students fluent in English and Turkish and the overall scores from the Turkish forms that were reapplied one week later are given in Table 9. Item correlation coefficients are given in Table 10, and the related group $t$-test results are given in Table 11. 
Table 9.

The Results of the Pearson Moments Correlation Analysis Between the Original and Turkish forms

\begin{tabular}{lcccc}
\hline Application & $\boldsymbol{n}$ & & $\boldsymbol{S D}$ & $\boldsymbol{r}$ \\
\hline Turkish form & 42 & 61.76 & 2.02 & $.75^{* *}$ \\
English form & 42 & 61.95 & 2.70 & \\
\hline
\end{tabular}

$* * p<.01$

As shown in Table 9, the correlation coefficient between scores from the English and Turkish forms is $r=.75(p<.01)$.

Table10.

Item Correlation Coefficients Between the Turkish and English Forms

\begin{tabular}{lccc}
\hline Item & $\boldsymbol{n}$ & $\boldsymbol{r}$ & $\boldsymbol{P}$ \\
\hline $\operatorname{Tr} 01$ \& Eng 01 & 42 & .78 & .000 \\
Tr 02 \& Eng 02 & 42 & .91 & .000 \\
$\operatorname{Tr} 03$ \& Eng 03 & 42 & .57 & .000 \\
Tr 04 \& Eng 04 & 42 & .69 & .000 \\
$\operatorname{Tr} 05$ \& Eng 05 & 42 & .68 & .000 \\
$\operatorname{Tr} 06$ \& Eng 06 & 42 & .94 & .000 \\
$\operatorname{Tr} 07$ \& Eng 07 & 42 & .72 & .000 \\
$\operatorname{Tr} 08$ \& Eng 08 & 42 & .87 & .000 \\
$\operatorname{Tr} 09$ \& Eng 09 & 42 & .77 & .000 \\
$\operatorname{Tr} 10$ \& Eng 10 & 42 & .65 & .000 \\
$\operatorname{Tr} 11$ \& Eng 11 & .85 & .000 \\
$\operatorname{Tr} 12$ \& Eng 12 & 42 & .96 & .000 \\
$\operatorname{Tr} 13$ \& Eng 13 & 42 & .80 & .000 \\
$\operatorname{Tr} 14$ \& Eng 14 & 42 & .76 & .000 \\
$\operatorname{Tr} 15$ \& Eng 15 & 42 & .89 & .000 \\
$\operatorname{Tr} 16$ \& Eng 16 & 42 & .83 & .000 \\
$\operatorname{Tr} 17$ \& Eng 17 & 42 & .73 & .000 \\
$\operatorname{Tr} 18$ \& Eng 18 & 42 & .77 & .000 \\
$\operatorname{Tr} 19$ \& Eng 19 & 42 & .61 & .000 \\
$\operatorname{Tr} 20$ \& Eng 20 & 42 & .63 & .000 \\
\hline
\end{tabular}

Table 11.

Relevant Group t-Test Results for Linguistic Equivalence

\begin{tabular}{|c|c|c|c|c|c|c|c|c|c|c|c|}
\hline Item & Language & $\chi$ & $S D$ & $t$ & $p$ & Item & Language & $\chi$ & $S D$ & $t$ & $p$ \\
\hline \multirow[t]{2}{*}{1} & $\operatorname{Tr} 1$ & 2.79 & 1.52 & -.89 & .37 & 11 & $\operatorname{Tr} 11$ & 4.14 & 0.35 & .82 & .41 \\
\hline & Eng1 & 2.77 & 1.50 & & & & Eng 11 & 4.17 & 0.37 & & \\
\hline \multirow[t]{2}{*}{2} & $\operatorname{Tr} 2$ & 4.07 & 0.77 & -1.40 & .16 & 12 & $\operatorname{Tr} 12$ & 3.98 & 0.56 & -1.0 & .32 \\
\hline & Eng 2 & 3.42 & 1.28 & & & & Eng 12 & 4.00 & 0.58 & & \\
\hline \multirow[t]{2}{*}{3} & $\operatorname{Tr} 3$ & 4.21 & 0.52 & -.33 & .74 & 13 & $\operatorname{Tr} 13$ & 1.83 & 0.58 & -1.43 & .16 \\
\hline & Eng 3 & 4.33 & 0.52 & & & & Eng 13 & 1.81 & 0.45 & & \\
\hline \multirow[t]{2}{*}{4} & $\operatorname{Tr} 4$ & 1.86 & 0.56 & .35 & .72 & 14 & $\operatorname{Tr} 14$ & 1.81 & 0.63 & .44 & .66 \\
\hline & Eng 4 & 1.76 & 0.61 & & & & Eng 14 & 1.79 & 0.56 & & \\
\hline \multirow[t]{2}{*}{5} & $\operatorname{Tr} 5$ & 3.71 & 0.89 & -1.43 & .16 & 15 & $\operatorname{Tr} 15$ & 2.62 & 0.73 & -1.43 & .16 \\
\hline & Eng 5 & 3.76 & 0.93 & & & & Eng 15 & 2.50 & 0.74 & & \\
\hline \multirow[t]{2}{*}{6} & $\operatorname{Tr} 6$ & 4.29 & 0.45 & -1.0 & .32 & 16 & $\operatorname{Tr} 16$ & 2.28 & 1.21 & .61 & .54 \\
\hline & Eng 6 & 4.31 & 0.46 & & & & Eng 16 & 2.00 & 1.15 & & \\
\hline 7 & $\operatorname{Tr} 7$ & 2.50 & 0.89 & -.75 & .45 & 17 & $\operatorname{Tr} 17$ & 2.79 & 0.52 & .18 & .85 \\
\hline
\end{tabular}


Table 11.

Relevant Group t-Test Results for Linguistic Equivalence

\begin{tabular}{cccccccccccc}
\hline Item & Language & $\chi$ & $\boldsymbol{S D}$ & $\boldsymbol{t}$ & $\boldsymbol{p}$ & Item & Language & $\chi$ & $\boldsymbol{S D}$ & $\boldsymbol{t}$ & $\boldsymbol{p}$ \\
\hline \multirow{4}{*}{8} & Eng 7 & 2.50 & 1.01 & & & & Eng 17 & 2.40 & 1.21 & & \\
& $\operatorname{Tr} 8$ & 3.74 & 0.88 & -.46 & .64 & 18 & $\operatorname{Tr} 18$ & 3.71 & 0.63 & -0.37 & .71 \\
9 & Eng 8 & 3.11 & 1.29 & & & & $\operatorname{Eng} 18$ & 3.74 & 0.58 & & \\
& $\operatorname{Tr} 9$ & 1.52 & 0.91 & -.48 & .62 & 19 & $\operatorname{Tr} 19$ & 3.76 & 0.75 & .28 & .78 \\
\multirow{4}{*}{10} & Eng 9 & 1.19 & 0.39 & & & & $\operatorname{Eng} 19$ & 3.83 & 0.53 & & \\
& $\operatorname{Tr} 10$ & 3.40 & 1.32 & -1.7 & .86 & 20 & $\operatorname{Tr} 20$ & 3.21 & 0.81 & -1.63 & .10 \\
& Eng 10 & 3.45 & 1.34 & & & & Eng 20 & 3.38 & 0.73 & & \\
\hline
\end{tabular}

As can be seen in Tables 10 and 11, no significant difference exists between the results from the relevant group's $t$-tests in which the Turkish version of the Scale for Spiritual Intelligence was equated to the original English form. According to all results, the Turkish form of the scale is equivalent to the English form.

\section{Criterion-Based Validity Study for the Scale for Spiritual Intelligence}

The criterion-based validity of the Scale for Spiritual Intelligence was examined in terms of its relationship with the Meaning in Life Scale. The findings showing the correlation coefficients and descriptive statistics between the scales and their subdimensions are given in Table 12.

Table 12 .

Correlation Coefficients for the Relationship between Overall Scores from the Scale for Spiritual Intelligence and the Meaning in Life Scale

\begin{tabular}{lcc}
\hline Variables & $\mathbf{1}$ & $\mathbf{2}$ \\
\hline 1. Spiritual Intelligence & 1 & $.57^{* *}$ \\
2. Meaning in Life & & 1 \\
Average O & 60.38 & 44.85 \\
Standard Deviation $(S D)$ & 3.70 & 10.12 \\
\hline
\end{tabular}

$* * p<0.01$

Table 12 shows a positive correlation to exist between the overall scores from the Scale for Spiritual Intelligence Scale and the Meaning in Life Scale (.57).

\section{Item Analysis of the Scale for Spiritual Intelligence}

Unrelated Group T-Test was performed to examine the distinctiveness of the Spiritual Intelligence Scale and to examine whether the scores of the two groups consisting participants of $27 \%$ lower slice and $27 \%$ upper slice differed statistically. The completed analysis results are given in Table 13.

Table 13.

T-Test results of 27\% of the Spiritual Intelligence Scale for Lower and Upper Groups

\begin{tabular}{llcccccc}
\hline Scores & Groups & $\boldsymbol{n}$ & $\boldsymbol{\chi}$ & $\boldsymbol{S D}$ & $\boldsymbol{S E}$ & $\boldsymbol{t}$ & $\boldsymbol{p}$ \\
\hline \multirow{2}{*}{ Spiritual Intelligence Scale } & Upper & 130 & 84.65 & 2.94 & .25 & 49.707 & .000 \\
& Lower & 130 & 64.26 & 3.63 & .31 & & \\
\hline
\end{tabular}


As a result of the independent $t$-test completed with respect to the Scale for Spiritual Intelligence, a statistically significant difference has been found between the lower and upper groups in favor of the upper group $(t=49.707, p<.001)$. In line with this result, the Scale for Spiritual Intelligence can generally be concluded as a successful measurement tool for distinguishing individuals' spiritual intelligence.

\section{Relationships Among the Sub-Dimensions of the Scale for Spiritual Intelligence}

Pearson correlation analysis has been completed in order to examine the relationships among the sub-dimensions of the Scale for Spiritual Intelligence. The analysis results are given in Table 14 .

Table 14.

Relationships Among the Sub-dimensions of the Scale for Spiritual Intelligence

\begin{tabular}{|c|c|c|c|c|c|c|c|}
\hline Variables & $\chi$ & $S D$ & $\begin{array}{c}\text { Self } \\
\text { Understanding }\end{array}$ & $\begin{array}{c}\text { Human } \\
\text { Values }\end{array}$ & Compassion & Conscience & $\begin{array}{r}\text { Total } \\
\text { Score }\end{array}$ \\
\hline Self Understanding & 27.43 & 3.72 & 1 & & & & \\
\hline Human Values & 15.21 & 2.69 & $.50 * *$ & 1 & & & \\
\hline Mercy & 19.89 & 2.35 & $.47 * *$ & $.41 * *$ & 1 & & \\
\hline Conscience & 12.71 & 1.85 & $.47 * *$ & $.46^{* *}$ & $.35 * *$ & 1 & \\
\hline Whole Point & 75.25 & 8.23 & $.86^{* *}$ & $.78 * *$ & $.71 * *$ & $.69 * *$ & 1 \\
\hline
\end{tabular}

As a result of the performed analysis, statistically significant and positive relationships have been found among the sub-dimensions of the Scale for Spiritual Intelligence at the level of $p<.01$. In addition, statistically significant and positive relationships have been found among the total score from the Scale for Spiritual Intelligence and its sub-dimensions at the level of $p<.01$.

\section{Discussion}

This study was conducted to adapt the Scale for Spiritual Intelligence, which Kumar and Mehta (2011) performed to develop the concept of spiritual intelligence and determine adolescents' spiritual intelligence, into Turkish. For this purpose, the original form of the scale has been translated into Turkish by six people competent in English and Turkish. Two independent experts then translated the scale back into English. In maintaining the latest correction, the Turkish form was ready for application. The validity and reliability results from the Scale for Spiritual Intelligence show the scale to be a valid and reliable measurement tool. The Scale for Spiritual Intelligence, which originally consisted of six factors (self-understanding, human values, compassion, conscience, commitment towards humanity, and purpose of life) according to the performed exploratory factor analysis, consists of only four factors in the case of Turkey. These four factors are: self-understanding, human values, compassion, and conscience. As a result of the exploratory factor analysis, Item 3 was 
found to be included in a single sub-dimension; Item 3 was decided to be removed from the scale, as a single-factor sub-dimension is not possible. The final version of the scale, which was originally composed of 20 items, was adapted to Turkish culture with 19 items and four sub-dimensions (Self-understanding [Items 10, 1, 20, 5, 17, 2, 8], Human Values [Items 15, 14, 13, 16], Compassion [Items 12, 18, 11, 19, 6], and Conscience [Items 4, 9, 7]). In order to examine whether the new structure of the scale was verified as a result of exploratory factor analysis, confirmatory factor analysis over a second sample group shows the four sub-dimensional structures to be confirmed and goodness-of-fit values to be generally acceptable.

However, in order to achieve a better model fit, the proposed suggestions for corrections were examined and the modification in accordance with these suggestions that constitutes the biggest difference in the $\chi^{2}$ value has been found to be related to errors from the Items 1 and 10 in the Scale for Spiritual Intelligence. As a matter of fact, when examining the contents of the scale items, both items were seen to have been included in the sub-dimension of self-understanding; the scale's items are similar in meaning and the proposed modification is supported theoretically. Accordingly, applying the proposed modification index was decided. The goodnessof-fit values obtained at the end of the process indicate the measuring instrument to have good and acceptable fit. In the reliability studies for the scale, Cronbach's alpha of internal consistency was found as .86 in the first sample group and .85 in the second sample. In the criterion validity study for the Scale for Spiritual Intelligence, its relationship with the Meaning in Life Scale, which is thought to have similar points in terms of the characteristics they measure, was examined and the overall scale scores were positively related. The independent $t$-test was performed to examine the distinctiveness of the Scale for Spiritual Intelligence and whether the scores from the upper and lower 27th-percentile groups differ statistically; a statistically significant difference was found between the lower and upper groups in support of the upper group $(t=49.707, p<.001)$. In line with this result, the Scale for Spiritual Intelligence can generally be considered a successful measurement tool for distinguishing individuals' spiritual intelligence.

When examining studies, few publications are seen to have aimed at measuring spiritual intelligence, and the groups are generally adults (Amram \& Dryer, 2008; King, 2008; Antunes, Silva, \& Oliveira, 2017). The Scale for Spiritual Intelligence, which had been integrated by Söylemez, Koç and Söylemez (2016), was adapted to Turkish culture for university students. No Turkish adaptation of any measurement tool is found for measuring high school students' spiritual intelligence. This study is considered able to support academic studies in the field of spiritual counseling that are being developing in Turkey The most important limitation of the study is that it consists of adolescents who are trying to gain their identity. Significant changes also exist in cognitive 
development during adolescence. According to Jean Piaget's cognitive development theory, adolescence starts after the age of eleven and is a period of abstract procedures. It is considered to end between the ages of 19 and 21, though this may vary. Abstract thoughts do not appear suddenly in adolescents; it is a slow process that goes beyond concrete experiences in order to make logical inferences and acquire the capacity to think idealistically and hypothetically in everyday life. Social and cultural structures are shown to have adequate conditions for transitioning to abstract processes. With the development of abstract thought, adolescents start to think and discuss concepts more often such as philosophy, religion, politics, and death (Derman, 2008). Spirituality, which is a sensitive and hard-to-measure concept, is also difficult to measure in groups of adolescents who are just starting the steps of abstract thinking and experiencing identity confusion; however, the main purpose of this study is to measure adolescents' spiritual intelligence and thus contribute to their values and moral development. Therefore, the attempt was made to keep the sample size large. Conducting the scale using larger samples in future studies may support the reliability of this study. Despite this limitation, the Turkish version of the Scale for Spiritual Intelligence can be said to be a valid and reliable scale in determining adolescents' levels of spiritual intelligence. Future studies can focus on the relationship of the Scale for Spiritual Intelligence with positive structures such as psychological well-being, hope, and life satisfaction and negative relationships such as depression, anxiety, and tendencies toward violence.

\section{References}

Amram, Y., \& Dryer, D.C. (2008). The Integrated Spiritual Intelligence Scale (ISIS): Development and preliminary validation. Boston, MA: American Psychological Association.

Antunes, R. R., Silva, A. P., \& Oliveira, J. (2018) Spiritual Intelligence Self-Assessment Inventory: Psychometric properties of the Portuguese version of SISRI-24. Journal of Religion, Spirituality \& Aging, 30(1), 12-24.

Bozdağ, M. (2005). Ruhsal zekâ. İstanbul: Nesil Yayınları.

Dereboy. İ. F., \& Dereboy, Ç. (1997). Batılılaşma ve kimlik direnci psikososyal bir yaklaşım. Cumhuriyet, demokrasi ve kimlik. İstanbul: Bağlam Yayıncılık.

Demirbaş, N. (2010). Yaşamda anlam ve yılmazlık (Yüksek Lisans Tezi, Hacettepe Üniversitesi, Sosyal Bilimler Enstitüsü, Ankara). Retrieved from https://tez.yok.gov.tr/UlusalTezMerkezi/

Demirbaş Çelik, N., \& İşmen Gazioğlu, E. (2015). Yaşamda Anlam Ölçeği lise formu: Türkçe geçerlik ve güvenirliği. Mehmet Akif Ersoy Üniversitesi Ĕ̆itim Fakültesi Dergisi, 33, 42-60.

Derman, O. (2008). Ergenlerde psikososyal gelişim, I.Ü. Cerrahpaşa Tip Fakültesi Sürekli Tıp Eğitimi Etkinlikleri, 63, 19-21.

Erikson, E. H. (1980). Identity and life cycle. New York, NY: W. W. Norton \& Company, Inc.

Hamer, D. (2004). The God gene. New York, NY: Anchor Books.

Hu, L., \& Bentler, P. M. (1999). Cutoff criteria for fit indexes in covariance structure analysis: Conventional criteria versus new alternatives. Structural Equation Modeling: A Multidisciplinary Journal, 6(1), 1-55. 
Jöreskog, K. G. \& Sörbom, D. (2001). LISREL 8.51 for Windows (Computer Software).

King, D. B. (2008). Rethinking claims of spiritual intelligence: A definition, model, and measure. Unpublished Master's Thesis, Trent University, Peterborough, Ontario, Canada. Retrieved from http://www.davidbking.net/thesis.pdf/

Koç, M. (2004). Gelişim psikolojisi açısından ergenlik dönemi ve genel özellikleri, Sosyal Bilimler Enstitüsü Dergisi, 17(2), 231-256.

Kumar, V.V., \& Mehta, M. (2011). Gaining adaptive orientation through spiritual and emotional intelligence. In A.K. Chauhan \& S.S. Nathawat (Eds.), New facets of positivism (pp 281-301). Delhi, India: Macmillan Publishers.

MacCallum, R. C., \& Hong, S. (1997). Power analysis in covariance structure modeling using GFI and AGFI. Multivariate Behavioral Research, 32(2), 193-210.

Marsh, H. W., Hau, K., \& Wen, Z. (2004). In search of golden rules: Comment on hypothesistesting approaches to setting cutoff values for fit indexes and dangers in overgeneralizing Hu and Bentler's (1999) findings. Structural Equation Modeling, 11, 320-341.

Nasel, D. D. (2004). Spiritual orientation in relation to spiritual intelligence: A new consideration of traditional Christianity and new Age/individualistic spirituality. Unpublished doctoral dissertation, University of South Australia, Australia. Retrieved from http://arrow.unisa.edu. au:8081/1959.8/24948/

Nazam, F. (2014). Gender difference on spiritual intelligence among adolescents. Indian Journal of Applied Research, 4(11), 423.

Persinger, M. A. (1996). Feelings of past lives as expected perturbations within the neurocognitive processes that generate the sense of self: Contributions from limbic lability and vectorial hemisphericity. Perceptual and Motor Skills, 83, 1107-1121.

Ramachandran, V. S., \& Blakeslee, S. (1998). Phantoms in the brain. London, UK: Fourth Estate.

Schermelleh-Engel, K., Moosbrugger, H., \& Muller, H. (2003). Evaluating the fit of structural equation models: Tests of significance and descriptive goodness-of-fit measures. Methods of Psychological Research Online, 8(2), 23-74.

Söylemez, A., Koç, M., \& Söylemez, B. (2016). The adaptation of Integrated Spiritual Intelligence Scale into Turkish. Journal of Family Counseling and Education. 1(1), 18-24.

Steger, M. F., Frazier, P., Oishi, S., \& Kaler, M. (2006). The meaning in life questionnaire: Assessing the presence of and search for meaning in life. Journal of Counseling Psychology, 53(1), 80-93.

Sümer, N. (2000). Yapısal eşitlik modelleri: Temel kavramlar ve örnek uygulamalar [Structural equation modeling: Basic concepts and applications]. Türk Psikoloji Yazıları, 3(6), 49-74.

Şimşek, Ö. F. (2007). Yapısal Eşitlik Modellemesine Girişs (Temel İlkeler ve LISREL Uygulamaları) (1st ed.). Ankara: Ekinoks.

Tabachnick, B. G., \& Fidell, L. S. (2001). Using Multivariate Statistics (4th ed.). Boston, MA: Allyn and Bacon.

Vaughan, F. (2002). What is Spiritual Intelligence? Journal of Humanistic Psychology, 42(2), 16-33. Wigglesworth, C. (2012). SQ: Spiritüel zekâ. (Seda Toksoy, Çev.). İstanbul: Kuraldışı Yayıncılık.

Zohar, D., \& Marshall, I. (2000). SQ: Ruhsal zekâmızla bağlantı kurmak. (B Erdemli \& K Budak. Çev.) İstanbul: Meta Basım Yayınları. 
